\title{
The Impact of Discovery Learning Model Based on High Order Thinking Skills (HOTS) in Learning Arabic on Students Analytical Thinking Skills
}

\author{
Ayu Desrani ${ }^{1}$, Zakiyah Arifa ${ }^{2}$, Susanto $^{3}$ \\ ${ }^{1}$ Sekolah Tinggi Agama Islam Sabili Bandung \\ 2Universitas Islam Negeri Maulana Malik Ibrahim Malang \\ 3Institut PTIQ Jakarta \\ Corresponding E-mail: aydesrani@gmail.com
}

\begin{abstract}
This research aimed to examine the impact of discovery learning model based on higherorder thinking skills (HOTS) on students analytical thinking skills in learning Arabic. The research was a quantitative approach and experiment method (quasi-experiment research), uses post-test control and experiment group design. The population in this research was the students of class X Islamic Senior High School (MAN) 1 Malang East Java, Indonesia. The sampling was taken using the cluster random sampling technique. The instrument used to collect data was a test balance. It was analyzed using SPPS with the independent sample ttest formula. The results of this research are: the significance value of variable analysis is $0.00<0.05$. It means there is an impact of the discovery learning model based on higherorder thinking skills (HOTS) on students' analytical skills. Implicitly, it can improve students abilities in understanding the material, therefore the students can think analytically when they find problems in learning.
\end{abstract}

Keywords: Discovery Learning, Higher Order Thinking Skills, Analytical Skills

\begin{abstract}
Abstrak
Penelitian ini bertujuan untuk mengetahui pengaruh model pembelajaran discovery learing berbasis hots terhadap kemampuan analisis siswa dalam pembelajaran bahasa arab. penelitian ini menggunakan pendekatan kuantitatif dengan metode eksperimen yang berjenis quasi eksperiment research dengan rancangan penelitian yang dipakai adalah Post-Test Only Control Group Design. Populasi dalam penelitian ini adalah siswa kelas X MAN 1 Kota Malang Jawa Timur Indonesia. Instrumen pengumpulan data yang digunakan berupa test dengan menggunakan uji analisis independent sample t-tes. Hasil penelitian ini adalah: Berdasarkan uji independent sample t-test diperoleh nilai signifikansi analisis variabel $0,00<0,05$ yang berarti terdapat pengaruh model discovery learning berbasis keterampilan berpikir tingkat tinggi terhadap kemampuan analisis siswa. Secara implisit dapat meningkatkan kemampuan siswa dalam memahami materi, sehingga siswa dapat berpikir analisis ketika menemukan permasalahan dalam pembelajaran.
\end{abstract}

Kata Kunci: Discovery Learning, Keterampilan Berpikir Tingkat Tinggi, Kemampuan Analisis

\section{Introduction}

Along with the implementation of the 2013 curriculum in schools, it is hoped that there will be many paradigm changes in the performance of learning activities in school or madrasah throughout Indonesia. Implementation of Curriculum 2013 according to Permendikbud No. 22/2016 on Standard Process 
using 3 (three) learning models which are expected to form scientific, social behavior and develop a sense of curiosity, one of which is discovery learning model (kemendikbud, 2012). The 2013 curriculum shapes students to have high-quality human resources to be able to compete in the current era of globalization. The demand in the current generation of globalization is that students must have 21stcentury skills. 21st-century skills are the skills that students have some skills include Higher Order Thinking Skills (Desrani et al., 2019;Astini, 2019;Mahmudi, 2020).

Furthermore, discovery learning is a mental process in which students can assimilate concepts (Rostiyah, 2008). Students try on their own to find solutions to problems so that they will provide significant knowledge. The stages of discovery learning include stimulation, problem statements, data collection, data processing, verification, and generalization. In discovery class, students' curiosity is very high so that learning outcomes are more optimal (Putrayasa, 2014). Therefore, discovery learning can improve analytical thinking skills (kemendikbud, 2012). As for learning Arabic following Mahyudin research, Discovery learning model can be developed in Arabic learning, this model is a modification of inductive learning by steps: (1) language exposure through examples or illustrations, (2) observation and language analysis through guiding questions, (3) formulation of language rules, (4) application of rules in practical assignments that are levelled based on the level of difficulty or complexity (Mahyudin, 2014).

One of the cognitive aspects of Bloom's taxonomy is the rank of knowledge, understanding, and application. All of them are the aspect of analysis (Saifer, 2017). Analytical thinking skills are an essential ability that must be possessed by students. Students may not achieve this analytical thinking ability if the student has not mastered the cognitive aspects beforehand. According to Sudjana, analysis is a complex type of outcome because it utilizes elements of knowledge, understanding, and application.

Another opinion that is in line, Suherman and Sukjaya (1990) states that the ability to analyze is the ability to detail or describe a problem (question) into smaller parts (components) and be able to understand the relationship between these parts. This kind is also reinforced by Bloom who stated that the ability to think analytically emphasizes the breakdown of material into more specific or 
The Impact of Discovery Learning Model Based on High Order Thinking Skills (HOTS) in Learning Arabic on Students Analytical Thinking Skills

smaller pieces and detects the relationships and the details and the features are organized (Kuswana, 2014).

If students can analyze a problem and can use what they already know into new nuances, it can be said that these students can solve the problem well. This ability is now known as High Order Thinking Skills. High Order Thinking Skills (HOTS) is the ability to manipulate, connect, and transform the knowledge and experience they have critically and creatively in defining decisions to solve problems in new situations (Saifer, 2017). In reality, in the field, the application of high order thinking skills-based learning models is difficult for educators to apply in teaching and learning activities. Besides, educators are required to master the high order thinking skills based materials and learning strategies; educators are also faced with a challenge with the environment and intake of the students they are teaching. As (Pratiwi, 2014) research states that the use of discovery learning models using a scientific approach is more impactive in learning to improve students' critical thinking skills, according to Sefer, critical thinking skills are part of analytical thinking skills. In line with research from Arif said that the use of hotsbased learning models could improve students' analytical skills which are higherorder thinking skills (Fanny, 2016).

The ability to think analytically according to Colin Rose and Malcom J. Nicholl: "The ability to think analytically can be viewed from analytical thinking in problem-solving, namely, defining exactly what the real problem is, having many ideas, getting rid of the least efficient alternatives and discarding options that do not meet the predetermined criteria, determine the ideal options by looking at the best solution that meets the established criteria, knowing the consequences and impacts in solving the problem"(Dafrita, 2017). Meanwhile, according to bloom in Krethwohl et al, part of the analysis thinking is divided into three, namely; 1) element or element analysis (analysis of parts of the material) The thing that is the focus of this indicator is problem-solving, as well as on the way o point of view of students in analyzing each element. 2) relationship analysis (identification of relationships) At this stage the indicator lies in the analysis of the relationship between elements, concerning everyday life, with existing theoretical concepts, and on the solutions given by students to the problems presented. 3) organizational analysis of organizational principles (organizational identification) 
At this stage, the indicators lie between the principles that have been devised by students at the previous stage with relevant theoretical concepts (Wilson, 2016).

In the 2013 curriculum learning, several paradigm changes have been used by teachers, and these changes are intended to adapt to the demands of the times and prepare Indonesian human resources to be ready to compete in the future. Learning with the 2013 curriculum trains students to find out, not only be told about science, guides students to think logically, systematically, and creatively, and emphasizes language skills as a means of communication (Kemendikbud, 2013;Desrani \& Zamani, 2021). Muruslin's research also states that the use of discovery learning-based learning models can strengthen the quality of learning in schools. According to him, the Discovery learning model is one of several learning models that should be understood by educators in carrying out learning to create masterpieces of the learning process that can change the learning atmosphere from passive to active and creative for students (Sirait, 2017). (Winoto \& Prasetyo, 2020; Chebaiki, 2021) the discovery learning model is a series of learning activities that maximally engage students with discovery techniques to search and investigate systematically, critically, and logically to try to solve their problems.

One of the language skills targeted in the 2013 curriculum is Arabic language skills. The state of Arabic in the 2013 curriculum structure for madrasas, is a compulsory subject for all types of specializations, especially MA based on the regulation of the minister of religion number 165 of 2014 So that to improve language skills, Arabic is one of the mandatory topics in Islamic Senior High School (MAN) 1 Malang East Java, Indonesia with the 2013 curriculum. The results of observations of learning Arabic in Islamic Senior High School (MAN) 1 Malang East Java, Indonesia are Arabic learning still tends to be teacher-centered. The teachers do not use varied methods while learning, the translation grammar and reading methods nevertheless dominate the used methods. In Arabic learning, where the poor man 1 teaches the four necessary skills. It's just that the focus of language proficiency is more emphasized on reading proficiency. While the learning media, in this case, the teacher never uses learning media except for handbooks and blackboards. However, based on teacher information, the media used are word cards, power points, and language laboratories. 
The Impact of Discovery Learning Model Based on High Order Thinking Skills (HOTS) in Learning Arabic on Students Analytical Thinking Skills

Based on the facts above, it is necessary to change the system in learning. The learning developed by the teacher is expected to encourage the improvement of higher-order thinking skills, increase creativity, and build the independence of students to solve problems. Therefore, researchers are interested in implementing the Arabic language learning used discovery learning models based on high order thinking in Islamic Senior High School (MAN) 1 Malang East Java, Indonesia.

\section{THEORY}

The discovery learning model is to understand concepts, meanings, and relationships through an intuitive process to finally arrive at a conclusion. Discovery occurs when the individual is primarily involved in using his mental process to discover concepts of things and principles. Discovery is done through observation, classification, measurement, prediction, prediction and reasoning. This process is called a cognitive process, and discovery itself is a mental process that absorbs concepts and principles in the mind (Arends, 2015). In the 2013 curriculum, this model is suggested to improve students' higher order thinking skills.

Thinking skills are usually categorized according to the type of learning to be achieved. The idea behind this is that certain types of learning require more cognition or deeper processing, such as critical thinking, analysis, and synthesis, while for other types of learning, recognition and recall may be sufficient. One of the most widely used classifications is the one proposed by Bloom, which aims to conceptualize and enhance advanced forms of thinking in education, including analysis and evaluation, as well as memorizing and recalling facts (rote memorization). It is commonly used to design courses and evaluate learning outcomes. In thinking skills classified by Blomm into several stages, namely as follows(Krathwohl, 2002): 
BLOOM'S TAXONOMY

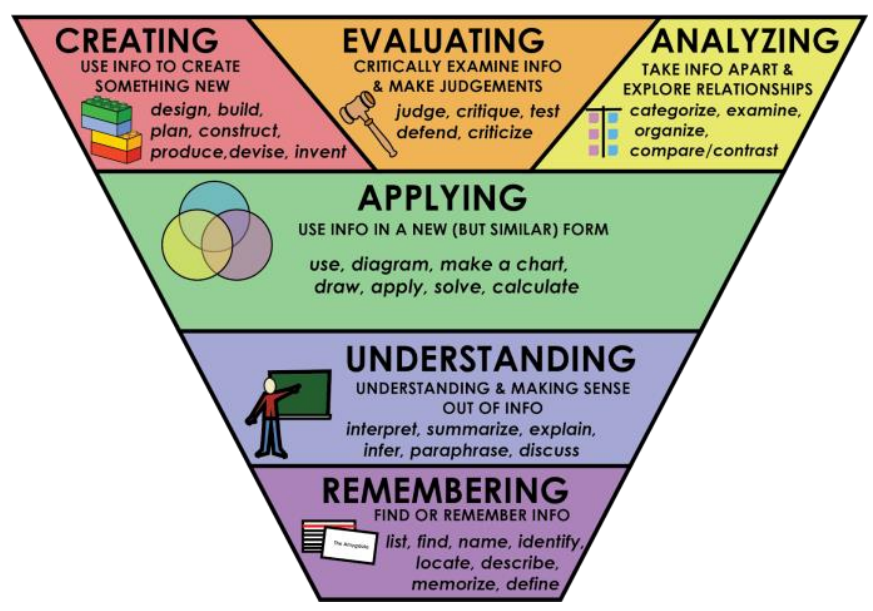

Figure 2. Bloom's Taxonomy

based on the image above, Analytical thinking is included in higher order thinking skills, or better known as HOTS (high order thinking skills). The definition of analytical thinking itself is the ability to overcome a problem based on the information possessed. Information that is complex or comprehensive is broken down into principle and basic information(Krathwohl, 2002). This produces detailed information that will assist the individual in formulating a solution to the problem. As the name implies, this way of thinking relies on a fairly in-depth analysis process.

\section{METHOD}

Based on the problems and research objectives described above, this research uses a quantitative approach with a quasi-experimental research method with the research design used is Post-Test Only Control Group Design (Sugiyono, 2014). This research used two classes, namely the experimental class with the learning process using discovery learning models based on high order thinking skills and the control class using conventional learning models. At the end of this research, both classes will be given a test to see the results of their learning. The type of research can be seen in Table 1.

Table 1. Research Design

\begin{tabular}{|c|c|c|c|}
\hline Group & Pre-test & Treatment & Post-test \\
\hline Experiment & - & $\mathrm{X}$ & $\mathrm{T}$ \\
\hline Control & - & - & $\mathrm{T}$ \\
\hline
\end{tabular}


The Impact of Discovery Learning Model Based on High Order Thinking Skills (HOTS) in Learning Arabic on Students Analytical Thinking Skills

This research was conducted to students of class Islamic Senior High School (MAN) 1 Malang East Java, Indonesia in the 2019/2020 school year. The sampling in this research was taken using the cluster random sampling technique, which is taking two classes randomly from the population. Subsequently, the experimental class is obtained, namely class X language-1, which gets learning based on high order thinking skills. In contrast, class $\mathrm{X}$ language-2 gets learning as usual or conventional teachers apply. Partners, as the control class (Walenta, 2019). This hypothesis reads as follows.

Ho: There is no positive and significant impact of the use of hots-based inquiry learning models on the analytical thinking skills of class X Islamic Senior High School (MAN) 1 Malang East Java, Indonesia.

Ha: There is a positive and significant impact of the use of the hots-based inquiry learning model on the analytical thinking skills of class Islamic Senior High School (MAN) 1 Malang East Java, Indonesia.

The research was carried out in three stages, namely preparation, implementation, and completion. In this preparation stage, several things need to be done, namely, carrying out observations to the research site asking for the value of the daily test results. Next step is determining the experimental and control class, setting a research schedule, researching physics material for class XI semester I, preparing a Learning Implementation Plan (RPP), preparing the observation format for the practical assessment of students and observers to carry out assessments, prepare student high-order thinking skills question sheets for the experimental class, divide into heterogeneous groups, create a grid of test questions, compile test questions adjusted to the question grid that has been made, conducting test questions, and compiling final test questions based on the analysis of test questions. The implementation stage is learning carried out in the experimental class and the control class (Hodge, 2020). This test is given to obtain the value of learning outcomes in the cognitive domain and collect data on the learning outcomes of students' practical domain through the affective domain assessment format every time the meeting takes place and to analyze the learning outcomes of the cognitive and cognitive domains impactive through statistical tests using SPSS 22. 


\section{RESULTS AND DISCUSSION}

Before doing data analysis, the researcher first applies the learning using guided discovery learning model. This model can be easily applied to any foreign language class and at any level, including Arabic classes. as for the steps: first, exposure of language through examples or illustrations, the teacher exposes the language to students through illustrations, examples, or a combination of the two. Examples can be presented in the form of loose sentences, although it should be remembered that it is more effective to introduce language to context. Language contextualization can be done through reading or listening to a text, illustration/photo, or real-life topics and situations, thus making grammar more relevant and lively. As an example applied to students in lessons that focus on the form of isim nakirah and isim ma'rifah. The first step is to show students the list of words as below, then students are directed to understand the meaning of each word through various techniques including pictures.

$$
\text { كتابٌ - الكتاب - مدرسـةٌ - المدرسة - طالبُ - الطالب }
$$

Second, observation and language analysis through guiding questions. The teacher guides the observation by drawing attention to the points to be explained. In the example above, the teacher could ask students to think of each type of word and its differences. Third, the preparation or formulation of linguistic rules. The teacher uses the information from step two to create, or direct students to state their formulation of the rule they are learning. This activity is important to ensure that all students understand the targeted rules correctly. Fourth, the application of rules in practical tasks which are levelled based on the level of difficulty or complexity. This step aims to put the language into practice. The teacher assigns several tasks ranging from controlled exercise forms (such as: mentioning types of words, matchmaking, filling in the blanks, and closed questions) to more communicative and meaningful forms of exercise (such as open questions for discussion, role-playing, writing assignments, and so forth).

The analysis in this research was to determine the impact of high order thinking skills-based discovery learning models on students analytical thinking skills in Arabic subjects. The standard of analytical skills originating from the PISA 
The Impact of Discovery Learning Model Based on High Order Thinking Skills (HOTS) in Learning Arabic on Students Analytical Thinking Skills

(program for international student assessment) questions designed by the ministry of education and culture is as follows (Kemendikbud, 2017):

Table 2. structure of analytical thinking skills

\begin{tabular}{|l|l|l|l|}
\hline No & Analyzing & Indicator & Operational Verb \\
\hline 1 & Differentiating & $\begin{array}{l}\text { Be able to determine relevant } \\
\text { pieces of information }\end{array}$ & $\begin{array}{l}\text { Detect } \\
\text { Find } \\
\text { Select } \\
\text { Solve }\end{array}$ \\
\hline 2 & Organizing & $\begin{array}{l}\text { Be able to organize pieces } \\
\text { relevant information }\end{array}$ & $\begin{array}{l}\text { Detailing } \\
\text { Nominate } \\
\text { Rationalize } \\
\text { Examine }\end{array}$ \\
\hline 3 & Attributing & $\begin{array}{l}\text { Be able to determine the } \\
\text { purpose and relationship of } \\
\text { the information }\end{array}$ & $\begin{array}{l}\text { Correlate } \\
\text { Hook up } \\
\text { Conclude } \\
\text { Diagram } \\
\text { Imagine }\end{array}$ \\
\hline
\end{tabular}

Before analyzing the data, first conduct a prerequisite test, namely to ensure that the data obtained is normal and homogeneous. The normality test for data on students' analytical thinking skills the in experimental class obtained a value of 0.380 while in the control class, a value of 0.417 was obtained. This finding shows that the data for the two groups are generally distributed for the $5 \%$ significance level. Homogeneous data in both groups received a significance value of 0.418 , which means that it can be stated at the $5 \%$ significance level both groups are homogeneous.

Table 3. Descriptive Statistics

\begin{tabular}{|l|r|r|r|r|r|r|r|}
\hline & N & \multicolumn{1}{|c|}{ Range } & Minimum & Maximum & Mean & $\begin{array}{c}\text { Std. } \\
\text { Deviation }\end{array}$ & \multicolumn{1}{l|}{ Variance } \\
\hline Eksperiment & 32 & 30 & 60 & 90 & 75.16 & 8.375 & 70.136 \\
\hline Control & 32 & 40 & 40 & 80 & 60.00 & 9.672 & 93.548 \\
\hline Valid N & 32 & & & & & & \\
\hline
\end{tabular}




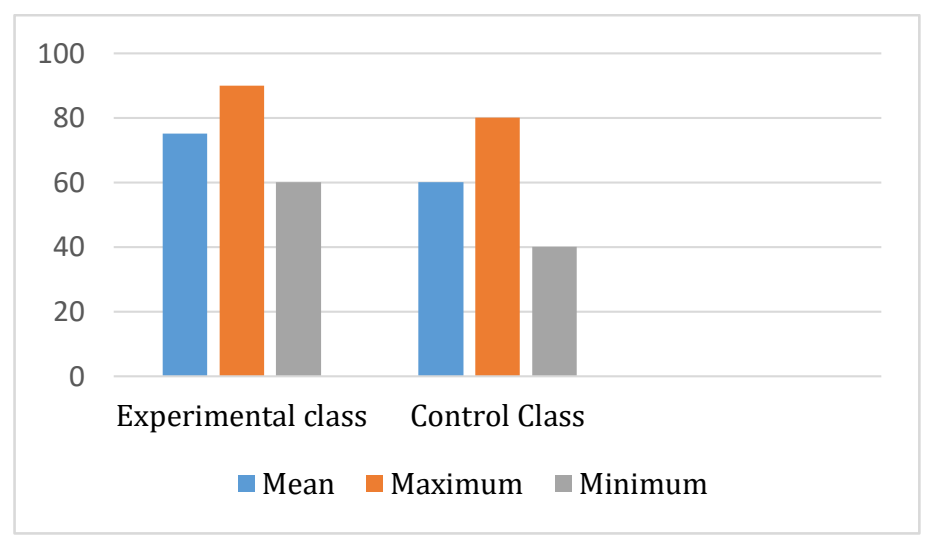

Figure 2. Comparison of the Learning Experiment and Control Scores

Based on the calculation of the table above, it can be seen that the average value of the post-test in the experimental class is 75.16 with a minimum value of 60 and a maximum of 90 . At the same time, the control class is 60.00 , with a minimum value of 40 and a maximum of 80 . This finding means that descriptively there is a difference the average between the control class and the experimental class using the discovery learning model in Arabic subjects.

Table 4. Independent Sample T-Test

\begin{tabular}{|c|c|c|c|c|c|c|c|}
\hline \multirow[b]{2}{*}{$\begin{array}{l}\text { Results of analytical } \\
\text { skills }\end{array}$} & \multicolumn{2}{|c|}{$\begin{array}{l}\text { Levene's } \\
\text { Test for } \\
\text { Equality of } \\
\text { Variances }\end{array}$} & \multicolumn{5}{|c|}{ t-test for Equality of Means } \\
\hline & $\mathrm{F}$ & Sig. & $\mathrm{t}$ & Df & $\begin{array}{l}\text { Sig. }(2- \\
\text { tailed) }\end{array}$ & Mean & Std. Error \\
\hline \begin{tabular}{|l}
$\begin{array}{l}\text { Equal variances } \\
\text { assumed }\end{array}$ \\
\end{tabular} & .665 & .418 & 6.701 & 62 & .000 & 15.15625 & 2.26167 \\
\hline $\begin{array}{l}\text { Equal variances not } \\
\text { assumed }\end{array}$ & & & 6.701 & 60.757 & .000 & 15.15625 & 2.26167 \\
\hline
\end{tabular}

The results of the independent sample t-test analysis in the table show that there is a positive influence between the $\mathrm{x}$ variable, namely the discovery learning model based on higher order thinking skills on the y variable students analytical thinking abilities in Islamic Senior High School (MAN) 1 Malang East Java, Indonesia. It is testing the second hypothesis using the independent sample t-test.

The criteria for testing the hypothesis, namely Ho is accepted if sig.2-tailed $>0.05$; otherwise, Ho is rejected if sig. 2 -tailed $<0.05$. Based on the t-test analysis or independent sample t-test, which can be seen in Table 3, the significance value for students' ability in analytical thinking is 0.00 , which means that Ho is rejected. This 
The Impact of Discovery Learning Model Based on High Order Thinking Skills (HOTS) in Learning Arabic on Students Analytical Thinking Skills

means that through the discovery learning model based on HOTS it can improve students' ability to understand the material. So that students can think analytically when they encounter problems in learning.

Based on the findings of this research, it was found that there was a significant the impact of discovery learning model based on high order thinking skills in Arabic learning on analytical thinking skills were known as high-order thinking skills which are one approach in learning where students are taught to think critically, logically, reflective, metacognitive, and creative thinking (Anderson et al., 2001). This ability to think will appear when individuals or students are faced with problems that they have not encountered before, this is in line with research conducted by Elfeky et al., suggesting HOTS-based learning has the benefit where students can manage critical thinking skills that connect and evaluate all aspects of a situation or problem (Setiawan et al., 2018). This statement includes collecting, organizing, remembering, and analyzing information.

Discovery learning model directs students to understand concepts, meanings, and relationships, through an inductive process that leads to a conclusion. With the use of the covered learning model, students are encouraged to identify what they want to know, then continue to look for information themselves and organize or shape what they know and understand in a final form (Ardyansyah \& Fitriani, 2020).

The stages of the discovery learning model in Arabic learning are as follows: (a) language material is presented from specific things (examples and illustrations) then to general conclusions (language rules or rules), (b) language rules or rules are taught implicitly first, it is only made explicit by students with teacher guidance, (c) prioritizing language exposure as information, facts, and data that will be processed by students to arrive at conclusions, (d) learning is coloured by disclosing language rules or rules, (e) learning prioritizes collaboration with peers, (f) student-centered learning who has autonomy and active participation, and (g) learning empowers problem-solving techniques (Mahyudin, 2014).

Discovery learning models affect improving critical thinking skills. According to Bloom, critical thinking skills are part of students' ability to analyze (Saifer, 2017). As did Martadai, et al. Which in their research states that discovery 
learning models are impactive in improving students' critical thinking skills. This model is said to be impactive because of the syntax in carrying out discovery learning activities so that students can solve problems that are impactive or have a significant impact on students' critical thinking abilities. Second, students are trained to think logically. Students can think logically when giving arguments in determining conclusions. Third, train students to think systematically (Larasati, 2020). Systematic thinking is that students follow the pattern of the scientific method, starting from observation, students asking questions based on the observations made; this can optimize their initial knowledge. As stated by Suastra, students' initial knowledge will have a positive impact on students, namely, understanding of concepts that will be stored in the long term (Kristin \& Rahayu, 2016).

Furthermore, Widana in his research said that learning with discovery learning model based on higher order thinking skills could improve student learning outcomes, where through the discovery learning model students were able to organize their material well (Widana, 2018). Furthermore, Fanny, in his research entitled hots-based learning can improve students' analytical skills. Here is because learning based on high order thinking skills is an ability of students that have managing critical, logical, reflective, metacognitive thinking, and creative thinking which are higher-order thinking skills. Learning based on high-order thinking skills is thinking ability that not only requires the ability to remember but requires other higher abilities, such as the ability to think creatively and critically so that students have this ability to analyze a problem (Fanny, 2016).

Higher order thinking skills include the ability to read with understanding and identify needed and unneeded material. The ability to draw correct conclusions from the data provided and be able to determine inconsistencies and contradictions in a group of data is part of critical thinking skills. In other words, Hots is analytical and reflexive (Heong et al., 2012). Furthermore, (Nagappan, 2001) argues that Higher Order Thinking Skills are critical to be applied in various aspects of knowledge. Because the learners are developed to learn higher-order thinking, teachers no longer tell students, but students must find out. Finding out what this means requires an intelligent and analytical thought process. To think smart and analytically means higher order thinking. Higher order thinking skills 
The Impact of Discovery Learning Model Based on High Order Thinking Skills (HOTS) in Learning Arabic on Students Analytical Thinking Skills

that are introduced early in school will have a positive impact later on. An educator must be able to read various phenomena and updated developments to develop, plan, and carry out a series of learning optimally to create a quality and quality educational process (Dinni, 2018). Students can independently read and identify various phenomena, challenges, problems, and developments so that they can lead and lead students to higher-order thinking skills (Raiyn, 2016).

In learning and research results, students are more likely to be able to identify existing relationships. For example, in learning when the teacher presents a text that tells an example story. Students can immediately relate the story to the experiences they experience in everyday life. This is under the opinion of Spradley which states that analysis is a way of thinking related to systematic testing of something to determine parts, relationships between parts and their relationship to the whole. Students are more dominant in being able to connect and identify material quickly because the material or stimulus provided is contextual (Aronson, 1995).

\section{CONCLUSIONS}

The stages in the discovery learning model based on higher-order thinking skills can encourage students to think analytically. The things that are supposed to affect students' ability to think analytically are active students, meaningful learning, and can solve problems. This finding is indicated by the results of student learning in student abilities, where the mean of students used discovery learning model based on higher-order thinking skills is 75.16, and the control class or used learning models conventional is 60.00. Not only that. Based on the independent sample t-test, the significance value of variable analysis was $0.00<0.05$, which means that there was an impact of the discovery learning model based on higher order thinking skills on students' analytical skills. Implicitly it can improve students' abilities in understanding the material, therefore the students can think analytically when they find problems in learning. especially in understanding grammar and reading

Based on the research that has been done, several things are suggested, namely 1) the HOTS-oriented Discovery learning model can be used as an alternative model by the teacher in all subjects including Arabic, 2) before it is implemented, the teacher should understand this model well to get the results. The 
maximum, 3) the teacher must be able to manage the time allocation properly so that learning with the Discovery Learning model based on higher order thinking skills can be carried out effectively. Not only this model can be combined with other models for maximum results, but also the other models.

\section{BIBLIOGRAPHY}

Anderson, L. W., Krathwohl, D. R. D. R., \& Bloom, B. S. (2001). A Taxonomy for Learning, Teaching, and Assessing. In New York Longman.

Ardyansyah, \& Fitriani, L. (2020). EFEKTIVITAS PENERAPAN METODE DISCOVERY LEARNING DALAM PEMBELAJARAN IMLA'. Al- Ta'rib, 8(2), 229-244.

Arends, R. (2015). Learning to Teach. McGraw-Hill International Edition.

Aronson, J. (1995). The Qualitative Report A Pragmatic View of Thematic Analysis A Pragmatic View of Thematic Analysis. J. The Qualitative Report.

Astini, N. K. S. (2019). Pentingnya Literasi Teknologi Informasi Dan Komunikasi Bagi Guru Sekolah Dasar Untuk Menyiapkan Generasi Milenial. Prosiding Seminar Nasional Dharma Acarya, 1(2018), 113-120.

Chebaiki, H. (2021). Pengembangan Desain Pembelajaran Bahasa Arab Berbasis Higher Order Thinking Skill Dengan Model Discovery Learning Pada Siswa Kelas X SMKM 8 Paciran. Al Mahāra: Jurnal Pendidikan Bahasa Arab, 7(1), 2744. https://doi.org/10.14421/almahara.2021.071-02

Dafrita, I. . (2017). Pengaruh Discovery Learning Terhadap Kemampuan Berpikir Kritis dan Analitis dalam Menemukan Konsep Keanekaragaman Tumbuhan. Jurnal Pendidikan Informatika Dan Sains.

Desrani, A., Kurniati, D., \& Adnani, K. (2014). HIGHER ORDER THINKING SKILLS THE 21st CENTURY. International Conference on Language, Education, Economic and Social Science. https://proceedings.iaipdnganjuk.ac.id/index.php/icoleess/article/view/12/2

Desrani, A., \& Zamani, D. A. (2021). Pengembangan Kurikulum Pembelajaran Bahasa Arab di Masa Pandemi Covid-19. Jurnal Alfazuna : Jurnal Pembelajaran Bahasa Arab Dan Kebahasaaraban, 5(22), 214-234.

Dinni, H. N. (2018). HOTS ( High Order Thinking Skills ) dan Kaitannya dengan Kemampuan Literasi Matematika. Prisma.

Fanny, A. M. (2016). IMPLEMENTASI PEMBELAJARAN BERBASIS HOTS DALAM MENINGKATKAN KEMAMPUAN ANALISIS MATA KULIAH PEMBELAJARAN IPS DI SEKOLAH DASAR. JPD: Jurnal Pendidikan Dasar.

Heong, Y. M., Yunos, J. M., Othman, W., Hassan, R., Kiong, T. T., \& Mohamad, M. M. (2012). The Needs Analysis of Learning Higher Order Thinking Skills for Generating Ideas. Procedia - Social and Behavioral Sciences. https://doi.org/10.1016/j.sbspro.2012.09.265

Hodge, S. R. (2020). Quantitative research. In Routledge Handbook of Adapted Physical Education. https://doi.org/10.4324/9780429052675-12

Kemendikbud. (2013). Modul pembelajaran 2013. Kewirausahaan. 
The Impact of Discovery Learning Model Based on High Order Thinking Skills (HOTS) in Learning Arabic on Students Analytical Thinking Skills

Kemendikbud. (2017). Modul Penyusunan Higher Order Thingking Skill (HOTS). Direktorat Pembinaan Sma Direktorat Jenderal Pendidikan Dasar Dan Menengah Departemen Pendidikan Dan Kebudayaan 2017.

KEMENDIKBUD. (2012). Model pembelajaran penemuan (discovery Learning). Jurnal Model Pembelajaran Discovery Learning .

Krathwohl, D. R. (2002). A Revision of Bloom 's Taxonomy: Theory Into Practice.

Kristin, F., \& Rahayu, D. (2016). PENGARUH PENERAPAN MODEL PEMBELAJARAN DISCOVERY LEARNING TERHADAP HASIL BELAJAR IPS PADA SISWA KELAS 4 SD. Scholaria: Jurnal Pendidikan Dan Kebudayaan. https://doi.org/10.24246/j.scholaria.2016.v6.i1.p84-92

Kuswana, W. S. (2014). Taksonomi kognitif. In PT Remaja Rosdakarya.

Larasati, D. A. (2020). PENGARUH MODEL DISCOVERY LEARNING BERBASIS HIGHER ORDER THINKING SKILL TERHADAP KEMAMPUAN BERPIKIR KRITIS. VOX EDUKASI: Jurnal Ilmiah Ilmu Pendidikan. https://doi.org/10.31932/ve.v11i1.684

Mahmudi, A. (2020). Tantangan Guru Bahasa Arab dalam Menerapkan Higher Order Thinking Skills (HOTS) pada Pembelajaran Keterampilan Berbicara di Madrasah Aliyah Negeri Kota Malang. Universitas Islam Negeri Maulana Malik Ibrahim Malang.

Mahyudin, E. (2014). Model Pembelajaran Diskoveri Sebagai Strategi Pembelajaran Bahasa Arab. ARABIYAT: Jurnal Pendidikan Bahasa Arab Dan Kebahasaaraban, 1(2). https://doi.org/10.15408/a.v1i2.1139

Nagappan, R. (2001). The Teaching of Higher-Order Thinking Skills in Malaysia. Journal of Southeast Asian Education, 2(1), 23-35.

Pratiwi, F. A. (2014). Pengaruh Penggunaan Model Discovery Learning Dengan Pendekatan Saintifik Terhadap Keterampilan Berpikir Kritis Siswa Sma (Issue 6). UNIVERSITAS TANJUNGPURA PONTIANAK.

Putrayasa, I. M., Syahruddin, H., \& Mergunayasa, I. G. (2014). Pengaruh Model Pembelajaran Discovery Learning Dan Minat Belajar Terhadap Hasil Belajar Ipa Siswa. Jurnal Mimbar PGSD Universitas Pendidikan Ganesha.

Raiyn, J. (2016). The Role of Visual Learning in Improving Students' High-Order Thinking Skills. Journal of Education and Practice.

Rostiyah. (2008). Strategi Belajar Mengajar, Cet-7. Rineka Cipta.

Saifer, S. (2017). Higher Order Thinking Skills; Developing Higher Order Thinking in Young Learners. In Redleaf Press.

Setiawan, A., Malik, A., Suhandi, A., \& Permanasari, A. (2018). Effect of Higher Order Thinking Laboratory on the Improvement of Critical and Creative Thinking Skills. IOP Conference Series: Materials Science and Engineering. https://doi.org/10.1088/1757-899X/306/1/012008

Sirait, M. (2017). Model Pembelajaran Berbasis Discovery- Inkuiri dan Kontribusinya Terhadap Penguatan Kualitas Pembelajaran di Sekolah Dasar. AR-RIAYAH : Jurnal Pendidikan Dasar, 1(2), 155. https://doi.org/10.29240/jpd.v1i2.320 
Sugiyono. (2014). Metode Penelitian Kuantitatif Kualitatif dan $R \&$ D. ALFABETA.

Walenta, M. (2019). Research method. In Second Language Learning and Teaching. https://doi.org/10.1007/978-3-030-04699-6_4

Widana, I. W. (2018). Higher Order Thinking Skills Assessment towards Critical Thinking on Mathematics Lesson. International Journal of Social Sciences and Humanities (IJSSH). https://doi.org/10.29332/ijssh.v2n1.74

Wilson, L. O. (2016). Anderson and Krathwohl Bloom's Taxonomy Revised Understanding the New Version of Bloom's Taxonomy. The Second Principle.

Winoto, Y. C., \& Prasetyo, T. (2020). EFEKTIVITAS MODEL PROBLEM BASED LEARNING DAN DISCOVERY LEARNING TERHADAP KEMAMPUAN BERPIKIR KRITIS SISWA SEKOLAH DASAR. Jurnal Basicedu. https://doi.org/10.31004/basicedu.v4i2.348 